\title{
W POSZUKIWANIU ŹRÓDEŁ MOTYWU UCZNIA CZARNOKSIĘŻNIKA: MięDZy LuKianem a Waltem Disneyem
}

\author{
Damian KaLITAN \\ damian.kalitan@uj.edu.pl
}

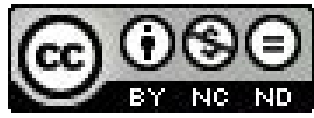

17 grudnia 1999 r. światową premierę miał, dopracowywany przez kilka lat, film animowany pt. Fantazja 2000, który cieszył się długie lata niezwykłą popularnością. Na fali jego sukcesu wytwórnia Walt Disney Picture zdecydowała się nakręcić film pt. Uczeń czarnoksiężnika (ang. The Sorcerer's Apprentice) w reżyserii Johna Turteltauba. Inspiracją do jego powstania była jedna ze scen z filmu Fantazja 2000. Szukając pierwowzoru pomysłu na wykorzystanie postaci ucznia czarnoksiężnika od razu znajdziemy informacje, że oba filmy czerpały inspirację z ballady Johanna Wolfganga Goethego z 1797 r. zatytułowanej właśnie Uczeń czarnoksiężnika (niem. Der Zauberlehrling). Niemniej, źródeł tego motywu należy szukaćjeszcze w starożytności. W XIX i XX w. zapomniano, poniekąd, o antycznych korzeniach tej historii i wszystkie zasługi przypisano J. W. Goethemu. W moim artykule postaram się wskazać pierwotną inspirację dla motywu ucznia czarnoksiężnika, jednak by tego dokonać należy sięgnąć do II w. n. e.

Lukian z Samosat był czołowym przedstawicielem okresu tzw. drugiej sofistyki i jednym z najoryginalniejszych pisarzy greckich. Wiadomo o nim, tylko tyle, ile sam o sobie przekazał, zwłaszcza w dwóch dialogach uważanych za autobiograficzne: Sen i Podwójnie oskarżony. Urodził się on ok. 120 r. n. e. w Samosatach nad Eufratem, a zmarł ok. 190 r. n. e. Pochodził z niezamożnej rodziny. Uczył się początkowo zawodu rzeźbiarza, który szybko porzucił, by studiować retorykę i filozofię. Sam pisze o tym w dialogu Sen. Dzięki usilnej pracy opanował doskonale język grecki. W samej starożytności można odnaleźć o nim zaledwie parę bezpośrednich wzmianek i niewiele więcej pośrednich dowodów na znajomość jego twórczości ${ }^{1}$. Sytuacja ta poprawia się znacząco w okresie bizantyjskim.

Pierwsze istotne informacje o Samosateńczyku przekazuje Focjusz (IX w.) w kodeksie 128 swojej Biblioteki. Następnie wspomina o nim uczeń Focjusza i zajadły krytyk Lukiana, Aretas (IXX w.). Na jego polecenie przepisano rękopisy, między innymi z tekstami Lukiana. Aretas pisał na nich swoje odręczne notatki (scholia), które zachowały się do naszych czasów². Popularność Lukiana rosła. Zaczęto tworzyć anonimowe dialogi wzorowane na lukianowych i dołączać je do zbioru jego pism. Pełnymi garściami z Lukiana literacko czerpał Teodor Prodromus (XII w.) a do jego lektury zachęcał Michał Psellos ${ }^{3}$. Wspomina o nim również Księga Suda. Notatka na jego temat kończy się stwierdzeniem: „,kary piekielne, na które zasłużył Lukian, trwać będą całą wieczność" ${ }^{4}$. Autor tylko niewiele się pomylił, bo nie kary Samosateńczyka trwają wiecznie, ale wpływ, jaki jego teksty wywarły na kulturę trwa aż po dzień dzisiejszy.

Nie jest pewne, kiedy dokładnie pisma Lukiana pojawiły się w Europie. Podaje się kilka możliwości. Jeden z tropów wskazuje, że Giovanni Aurispa, podczas swojej podróży do Konstantynopola w 1425 r., przywiózł wśród 238 greckich manuskryptów, między innymi ten z pismami

T. Sinko, Literatura grecka, t. 3: Literatura grecka za cesarstwa rzymskiego, cz. 1, Kraków 1951, s. 367-444.

W. Madyda, Bizantyjska polemika z Lukianem, „Meander” 1946, nr 1, s. 468- 476.

3 Więcej o znajomości Lukiana w Bizancjum zob. S. Hammer, O bizantyńskich podróżach do piekiet, „Meander” 1948, nr 3, s. 27-32.

4 K. Holzman, Starożytne i bizantyńskie opinie o Lukianie - pisarzu i człowieku, „Meander” 1983, nr 38, s. 29-44. 
Lukiana. Inne źródła podaja, że manuskrypt przywiózł ok. 1408 r. Gurino Guarini i niebawem kilka z utworów wydał w tłumaczeniu łacińskim. Jeszcze inne źródło wskazuje, że w 1397 r. Manuel Chrysoloras przywiózł do Florencji manuskrypt z pismami Lukiana, by na nich uczyć swego podopiecznego greki. Zgodności nie ma również odnośnie czasu editio princeps. Podawane daty to: 1496 r. i 1525 r., natomiast jednomyślnie za miejsce pierwszej edycji wskazuje się Florencję․ Od opublikowania drukiem zaczyna się zawrotna kariera Lukiana w Europie, a pierwsze tłumaczenia na łacinę ukazują się niemal natychmiast po przewiezieniu rękopisów. Na włoskich uczonych, niezaznajomionych jeszcze z językiem greckim, satyryk wywiera pierwszy wpływ właśnie poprzez łacińskie tłumaczenia. Już Leone Battista Alberti w swoim dziele De pictura, wydanym w 1435 r., pisze o Lukianie: „Inwencja bowiem ma w sobie taką siłę, że może zainteresować nawet bez połączenia ze sztuką malarską. Lukian w ten sposób podaje opis obrazu Apellesa pt. Potwarz, że czytając odczuwa się podziw dla sztuki Apellesa. (...) Dlatego radzę, ażeby malarz zapoznał się z poetami, mówcami, innymi znawcami literatury i odnosił się do nich życzliwie" ${ }^{\prime \prime}$. Malarze wzięli sobie do serca słowa włoskiego teoretyka i, jak pisze Tadeusz Sinko o wpływie Lukiana na sztukę: „Tylu pędzli nie puściły w ruch nawet opisy obrazów antycznych Filostrata"7. Znajomość Lukiana szybko objęła całą Europę, czerpali z niego Botticelli, Leonardo da Vinci, Rafael, Rubens, Dürer i wielu innych. Można to zauważyć śledząc popularność, u wielu malarzy renesansowych, motywu Kalumnii czy Rodziny centaurów. Samosateńczykiem były zafascynowane najtęższe umysły epoki. Erazm z Rotterdamu, gdy tylko opanował grekę, zaczął tłumaczyć niektóre jego dialogi w tym Łgarz albo Niedowiarek (gr. Philopseudes). Sam Erazm również nie pozostał bez wpływu Lukiana. Motyw literacki w swojej Pochwale głupoty zaczerpnął właśnie z Lukiana ${ }^{8}$. Wybitny matematyk i astronom Jan Kepler prowadził swoje obserwacje astronomiczne zainspirowany lukianową Prawdziwa Historia i Ikaromenipposem. Napisał nawet powieść fantastyczną utrzymaną w duchu Lukiana pt. Sen, czyli wydane pośmiertnie dzieło poświęcone astronomii księżycowej".

Aby pełniej przedstawić dzieje omawianego motywu, chciałbym najpierw zająć się lukianowym dialogiem Philopsudes (Łgarz albo niedowiarek), który jest szczególnie interesujące przy poszukiwaniach źródeł ucznia czarnoksiężnika. Tekst i jego zamysł literacki jest niezwykle ciekawy. Formą (ale nie tylko) nawiązuje Lukian do dialogów Platona, prezentując nam dialog diegetyczny $^{10}$. Niejaki Tychiades (utożsamiany z autorem) opowiada swemu przyjacielowi Filoklesowi przebieg niedawnych odwiedzin u ich wspólnego znajomego Eukratesa, który jest chory. Jego przyjaciele umilali mu czas opowiadaniem rzekomo prawdziwych historii. Po tej ramie otwarcia czytelnik zostaje zapoznany z serią dziesięciu niezwykłych opowieści (czy raczej relacją z tych opowieści). Tychiades wchodząc do pokoju chorego, wkracza też w środek dyskusji lokalnych znakomitości. Prócz gospodarza Eukratesa obecni są: platonik Ion, perypatetyk Kleodem,

\footnotetext{
5 Kwestia przywiezienia rękopisu do Europy i daty editio princeps porównaj: T. Sinko, dz. cyt., s. 435-346; K. Korus Michał Bogucki-tłumacz Lukiana, „Meander” 1968, nr 10, s. 131; J. Miziołek „Rodzina centaurów” Louis de Silvestre'a w Pałacach Prezydenckim i w Wilanowie. O recepcji ekphrasis Lukiana w polskiej kulturze artystycznej, „Biuletyn Historii Sztuki” 2003, nr 1, s. 43-46; C. Ligota (red.), Lucian of Samosata. Vivus et Redvivus, London - Turin 2007, ss. 9-13, 71-114; E. P. Goldschmidt, The First Edition of Lucian of Samosata, "Journal of the Warburg and Courtauld Institutes" 1951, nr 14, s. 7-20.

6 J. Białostocki, Myśliciele, kronikarze i artyści o sztuce od starożytności do 1500 r., Warszawa 1978, s. 112.

T. Sinko, dz. cyt., s. 429.

8 H. Barycz, Wstęp [w:] Erazm z Rotterdamu, Pochwała głupoty, Wrocław 1953, s. XXXVI-LXXXIV.

9 Więcej o recepcji Lukiana zob. C. Ligota, dz. cyt.; Ch. Robinson, Lucian and his Influence in Europe, Chapel Mill 1979; T. Sinko, dz. cyt., s. 428-435.

10 Dialog diegetyczny - dialog zamieszczony w opowiadaniu osoby relacjonującej przebieg rozmowy.
} 
pitagorejczyk Arignotus, hippokratejczyk Antigonus i stoik Dinomachus. Skład uczestników nie bez powodu przywołuje na myśl skojarzenie z Ucztą Platona ${ }^{11}$. Tychiades słysząc, że rozmawiają oni o cudownych sposobach wyleczenia nogi Eukratesa zaczyna ganić ich naiwność i przeciwstawiać się zabobonnemu myśleniu. Niestety, obecni w pokoju nie słuchają racjonalnych argumentów swego oponenta, a wręcz zaczynają jeden po drugim opowiadać cudowne historie, by przekonać Tychiadesa, że zdarzenia nadprzyrodzone mają faktycznie miejsce i należy bardzo poważnie je traktować. Tychiades po każdej z opowieści oponuje, próbuje racjonalizować lub wprost szydzi z opowiadającego i tych, którzy mu wierzą. Jednak jego opór skutkuje jedynie opowiedzeniem kolejnej historii, jeszcze bardziej niesłychanej niż poprzednia, która to na pewno ma przekonać niedowiarka. W sumie, takich opowieści słyszymy dziesięć. Uczeni od lat próbują je jakoś tematycznie pogrupować, niemniej dotychczas nie udało się uzgodnić uniwersalnego podziału ${ }^{12}$.

Historia najbardziej istotna dla źródeł motywu ucznia czarnoksiężnika jest ostatnią opowiedzianą w dialogu. Daniel Ogden w swojej monografii nie bez powodu zatytułował ją właśnie jako historię Ucznia czarnoksiężnika. Przedstawia ją sam gospodarz. Opowiada on o swojej podróży do Egiptu, gdzie na statku płynącym po Nilu spotkał „,świętego męża” Pankratesa. Egipcjanina, który znał się na czarach, pływał na krokodylach i animował przedmioty codziennego użytku jak tłuczki, czy zasuwy do drzwi. Eukrates twierdzi, że jego nowy mentor nauczył go wszystkiego, co sam wiedział, nie chciał tylko zdradzić tajemnicy ożywiania przedmiotów. Jednak żądny wiedzy adept magii, podsłuchał raz formułę zabronionego zaklęcia i, gdy tylko jego mistrz wyszedł, postanowił je wypróbować. Zaklęcie podziałało a tłuczek ożywił się i usłuchał nakazu by przyniósł w wiadrze wody. Niestety, nadgorliwy uczeń nie znał zaklęcia zatrzymującego przedmiot, któremu raz wydano jakieś polecenie. Tłuczek nieprzerwanie nosił wodę do chaty i nie słuchał żadnych innych komend. Gdy Eukrates postanowił siłą zakończyć zaklęcie i gdy przepołowił tłuczek siekiera, po chwili miał już nie jednego, niestrudzonego nosiwodę, a dwóch. Sytuacja była już beznadziejna i Eukratesowi groziło utonięcie, lecz w ostatniej chwili zjawił się Pankrates i rozkazał tłuczkom, by znów stały się tylko tłuczkami. Sam zaś, po akcji ratunkowej wyszedł i już nigdy Eukrates go nie zobaczył. Jednakże, Tychiades i tej opowieści nie dał wiary, rozgniewany na zdziecinniałych towarzyszy, którzy wierzą w bujdy i bajki z hukiem opuścił zgromadzenie. Na tym się dialog kończy.

D. Ogden w swoim komentarzu-monografii do dialogu Philopseudes, skupia się głównie na antycznych źródłach dla samej opowieści o młodym adepcie magii. By wywnioskować skąd Lukian mógł czerpać inspiracje dla swojego opowiadania, wyszczególnił, na potrzeby swoich badań, kilka elementów, które są nieodłączne dla historii ucznia czarnoksiężnika. Do tych wyróżników zalicza się obecność młodego, zbyt ambitnego uczenia; pragnienie opanowania czaru nazbyt potężnego dla pomagiera maga, jak również księga zaklęć lub inny magiczny przedmiot, który wspomaga rzucenie czaru. Ponadto D. Ogden wylicza jeszcze animację jakiegoś martwego przedmiotu, utratę panowania nad czarem i próbę jego siłowego powstrzymania, oraz samego czarnoksiężnika-nauczyciela, który odmawia wyjawienia sekretnej formuły, a który na końcu ratuje śmiałka przed śmiercią. Uczony użył tych wyróżników, by zbadać wcześniejsze teksty pod kątem zbieżności z tekstem Lukiana ${ }^{13}$. Mi będą one pomoce, by wykazać podobieństwa późniejszych tworów kultury z tekstem Samosateńczyka. Wróćmy więc do recepcji jego dzieła.

${ }_{11}$ D. Ogden, In Search of the Sorcerer's Apprentice: The Traditional Tales of Lucian's Lover of Lies, Swansea 2007, s. 6-8.

12 Różne próby kategoryzacji i struktura dialogu por. D. Ogden, dz. cyt., 15-18.

13 D. Ogden, dz. cyt., s. 232-248. 
Lukian przez wieki inspirował najróżniejszych artystów. W XVIII w. pojawiły się pierwsze kompleksowe tłumaczenia Lukiana na języki narodowe, $\mathrm{z}$ francuskim na czele. W Niemczech zadania przetłumaczenia całości podjał się Christoph Martin Wieland. W 1788 r. na zaproszenie swojego serdecznego przyjaciela Johanna Wolfganga Goethego, przybył do Weimaru, gdzie przetłumaczył i opublikował pierwsze teksty Lukiana. Wśród nich było również tłumaczenie dialogu Philopseudes, czyli Łgarz albo niedowiarek. Goethe musiał znać te tłumaczenia, nawet jeśli wcześniej zapoznał się z dziełami Lukiana w tłumaczeniu łacińskim, czy też w greckim oryginale. Wyciągną on jedną z historyjek opowiedzianych $w$ tym dialogu i ułożył z tego motywu jedną z jego najbardziej znanych ballad, Der Zauberlehrling, opublikowaną w 1797 r. $^{14}$. Poemat J. W. Goethego oparty na lukianowym tekście, stał się znany w całej Europie. Pod wpływem tego utworu francuski kompozytor Paul Dukas (1865-1935) w 1897 r. skomponował scherzo symfoniczne pod tym samym tytułem (fr. L'apprenti sorcie). Scherzo to, uważa się za jedno z najwybitniejszych dzieł tzw. muzyki programowej. Oto, co sam kompozytor umieścił nad partyturą: „Pierwszą frazę skrzypiec na tle altówek i wiolonczel można nazwać »motywem czarów«. Motyw ten zawiera dwa elementy tematyczne, $\mathrm{z}$ których pierwszy pozostaje $\mathrm{w}$ dalszym przebiegu prawie niezmieniony, drugi zaś jest właściwym tworzywem całości (później intonuje go fagot jako »motyw miothy«). Drugi temat, bardzo ruchliwy i fantazyjny, charakteryzuje młodego ucznia. Wreszcie trzeci, energicznie skandowany i oparty na chromatycznych akordach, wyrażać ma »ideę panowania«, zwłaszcza w postludium, które przywraca spokojny nastrój wstępu" ${ }^{\prime 15}$.

Mając te przekazane przez kompozytora informacje i znając utwór J. W. Goethego, pracownicy W. Disneya postanowili włączyć ten motyw do swojego trzeciego (po Królewnie Śnieżce i Pinokiu) pełnometrażowego, animowanego filmu pt. Fantazja, który ukazał się w kinach, w 1940 r. Idea filmu polegała na tym, by do arcydzieł muzyki klasycznej dodać animacje i w ten sposób interpretować dźwięk poprzez obraz. Wykorzystano również muzykę P. Dukasa. Ścieżkę muzyczną nagrała Philadephia Orchestra pod batutą Leopolda Stokowskiego. Na tamte czasy, realizacja Fantazji, była nie lada wyzwaniem i kosztowała 125 tys. dolarów. Za to sama scena, weszła do klasyki kina. Premiera odbyła się 13 listopada 1940 r. W 1999 r., motyw z Uczniem czarnoksiężnika został reaktywowany również w filmie animowanym pt. Fantasia 2000, o czym była mowa w akapicie wstępnym.

Prześledziłem więc sposób, w jaki motyw ucznia czarnoksiężnika trafił początkowo do wysokiej kultury europejskiej, a następnie do kultury popularnej. Te trzy produkty kultury, mianowicie ballada J. W. Goethego, scherzo P. Dukasa i film W. Disneya są ze sobą nierozerwalnie związane. Elementem łączącym jest poemat J. W. Goethego, bez którego dalsza recepcja historii ucznia nie miałaby miejsca. $Z$ tego też powodu dzieła te są narracyjnie niemal identyczne. Śledząc akcje tematu filmowego opartego na balladzie Goethego, dostrzegamy motywy konstytuujące historię ucznia czarnoksiężnika wymienione przez D. Ogdena. W omawianej scenie występuje więc mag (Yen Sid), pod nieobecność którego młody adept sztuk tajemnych (Myszka Miki) próbuje wykorzystać księgę z czarami i magiczną czapkę, którą pozostawił wychodzący czarnoksiężnik. Myszka robi to, aby zmusić miottę do noszenia za nią wody do bani, podczas gdy sama zasypia chwilę potem. Budzi się, gdy sytuacja jest krytyczna, a na dodatek okazuje się, że miotła odmawia zaprzestania swojej pracy i cały czas przynosi ze studni pełne wiadra. Zdesperowany uczeń rozbija toporem na drobne drzazgi nieposłuszną miotłę, licząc, że pozbył się

${ }_{14}$ Treści ballady nie będę przytaczał, gdyż J. W. Goethe był wierny pierwowzorowi niemal zupełnie, zaś polskie tłumaczenie można przeczytać na stronie: http://j_uhma.republika.pl/uczen.html.

15 Cytowane za: http://pl.wikipedia.org/ hasło: Uczeń czarnoksiężnika (P. Dukas). 
problemu. Jednak po chwili, z każdej jednej drzazgi, w magiczny sposób, powstaje nowa miotła, która również chodzi po wodę. Tym sposobem, setki mioteł zalewają hektolitrami wody pracownię maga i w momencie, gdy Myszka Miki ma utonąć, na scenie pojawia się Yen Sid i trzema gwałtownymi gestami ratuje całą sytuację. Widzimy, że wszystkie zawarte tu wątki znaliśmy już wcześniej, niemal w identycznej konfiguracji, z opowiadania Lukiana.

Nieco inaczej wątek został poprowadzony w obrazie J. Turtletauba, który przejął tytuł Uczeń czarnoksiężnika dla całego filmu, nie tylko jednego epizodu. Niemniej fragment z wykorzystaniem muzyki P. Dukasa i ballady J. W. Goethego, który pierwotnie zainspirował twórców filmu, trwa jedynie 196 sekund, w porównaniu z ponad 10 minutowym epizodem w filmie Fantazja 2000. W scenie tej, muzyka bazuje na utworze P. Dukasa i wykorzystuje jej główny muzyczny temat. Sam film opowiada historię studenta fizyki Dave'a Stutlera (w tej roli Jay Baruchel), który okazuje się być ostatnim „merlinczykiem”, potomkiem wielkiego maga Merlina, znanego z legend arturiańskich. Jest on szkolony przez doświadczonego czarodzieja Baltazara (Nicolas Cage). Dave jest opornym i krnąbrnym uczniem. Pod nieobecność mistrza, chcąc zdążyć na randkę z dziewczyną i pod presją czasu, używa zaklęcia z księgi czarów, by wysprzątać pracownię. Uczeń ożywia tu nie tylko miotłę, ale gąbki, mydła, szczotki i zaprzęga je do pracy, a sam opuszcza chwilowo pomieszczenie. Sprawy szybko wymykują się spod kontroli, a ożywione przedmioty zamiast sprzątać, stają się złośliwe, nabierają cech charakterologicznych, zaczynają demolować i zalewać pracownię. Oczywiście próby odwrócenia zaklęcia, po powrocie do pracowni, na nic się zdają i główny bohater o mało nie ginie rażony prądem. Jak nie trudno się domyślić, swego ucznia w ostatniej chwili ratuje mag-nauczyciel. Na tym kończą się nawiązania do historii Lukiana w tym filmie. Lukianowski motyw był więc jedynie drobnym epizodem, wokół którego stworzono nową historię opowiedzianą na dużym ekranie, ponownie przedłużając w ten sposób żywotność starej opowieści.

Zajmując się problemem recepcji Lukiana, należy mieć świadomość jak bardzo często Lukian występuje jako hypotekst dla najróżniejszych tworów kultury (np. Szekspir i jego Tymon Ateńczyk inspirowany dialogiem Tymon albo odludek). W wielu wypadkach świadomość nawiązywania do Lukiana została dawno stracona, tak jak stało się to w przypadku ucznia czarnoksiężnika pomimo, że niemal cała literatura fantastyczna, wykorzystująca wątek podróży w kosmos, jest, po części, dłużna Lukianowi i jego Prawdziwej historii. To właśnie tam po raz pierwszy opisano podróże kosmiczne i „gwiezdne wojny", czyli walkę między mieszkańcami słońca a mieszkańcami księżyca, przy użyciu fantastycznych armii Konio-sępów, Pchło-łuczników, Kapusto-skrzydłych i in. Pisarze fantasy i science fiction zajmujący się problemem zbuntowanych tworów ludzkiej myśli technicznej lub medycznej wykorzystują to, co zostało nazwane „,syndromem ucznia czarnoksiężnika" (Sorcerer's Apprentice Syndrome). O syndromie tym, mówi się w odniesieniu do inżynierii genetycznej, broni jądrowej, robotyki i in. W książce R.U.R. napisanej w 1921 r., Karel Čapek, twórca słowa ",robot” i pionier fantastyki naukowej, przedstawia świat ludzi coraz bardziej zdominowany przez człekokształtne roboty, aż w końcu jeden z nich, o największym mózgu na świecie, jednoczy wokół siebie wszystkie pozostałe roboty i na ich czele staje do walki przeciw rodzajowi ludzkiemu. Pierwotna koncepcja Lukiana jest jednak ciagle przetwarzana przez szeroko pojętą kulturę popularną (w postaci buntujących się robotów, mutantów, ofiar eksperymentów genetycznych czy wirusów), choć nieraz w bardzo zmienionej formie. Oczywiście, różne formy recepcii Lukiana można by mnożyć, myślę jednak, że powyższe argumenty wystarczająco pokazały, że dziedzictwo Lukiana wciąż jest żywe i aktualne, a obecnie szczególnie silne jest w motywie ucznia czarnoksiężnika, odkrytym dla kultury europejskiej właśnie przez Samosateńczyka. 


\section{LiTERATURA PODMIOTU}

Kepler J., Sen, czyli wydane pośmiertnie dzieło pośzięcone astronomii księżycowej, przekł. D. Sutkowska, J. Włodarczyk, Warszawa 2004.

Lukian, Dialogi, t.1, Wrocław 1960.

Lukian, Dialogi, t. 2, przekł. M. Bogucki, Wrocław - Warszawa - Kraków 1962.

Lukian, Dialogi, t. 3, przekł. W. Madyda, Wrocław - Warszawa - Kraków 1966,

\section{LITERATURA PRZEDMIOTU}

Ligota C. (red.), Lucian of Samosata. Vivus et Redvivus, Warburg Institute Colloquia, London - Turin 2007. Barycz H., Wstęp [w:] Erazm z Rotterdamu, Pochwała głupoty, przekł. E. Jędrkiewicz, Wrocław 1953.

Białostocki J. (oprac.), Myśliciele, kronikarze i artyści o sztuce od starożytności do 1500 r., Warszawa 1978.

Goldschmidt E. P., The First Edition of Lucian of Samosata, "Journal of the Warburg and Courtauld Institutes" 1951, nr 14.

Hammer S., O bizantyńskich podróżach do piekiet, „Meander” 1948, nr 3.

Hardwick L., Stray C. (red.), A Companion to Classical Receptions, Oxford 2008.

Holzman K, Starożytne i bizantyńskie opinie o Lukianie - pisarzu i człowieku, Meander 1983, nr 38.

Holzman K., Studia o technice literackiej i osobowości twórczej Lukiana, Warszawa 1988.

Korus K., Michał Bogucki-tłumacz Lukiana, „Meander” 1968, nr 10.

Korus K., Poetyka Lukiana z Samosat. Kryteria oceny i wartościowania, Kraków 1982.

Korus K., Grecka proza poklasyczna, Kraków 2003.

Leśniodorski Z., Lucjan w Polsce, Kraków 1943.

Madyda W., Bizantyjska polemika z Lukianem, „Meander” 1946, nr 1.

Miziołek J., Inspiracje śródziemnomorskie, Warszawa 2004.

Miziołek J., „Rodzina centaurów" Louis de Silvestre'a w Pałacach Prezydenckim i w Wilanowie. O recepcji ekphrasis Lukiana w polskiej kulturze artystycznej, „Biuletyn Historii Sztuki” 2003, nr 1.

Ogden D., In Search of the Sorcerer's Apprentice: The Traditional Tales of Lucian's Lover of Lies, Swansea 2007.

Ogden D., Eucrates and Demainete: Lucian, "Philopseudes" 27-8, "The Classical Quarterly" 2004, nr 54.

Robinson Ch., Lucian and his Influence in Europe, Chapel Mill 1979.

Sinko T., Literatura grecka, t. 3: Literatura grecka za cesarstwa rzymskiego, cz. 1, Kraków 1951.

Sinko Z., Oświeceni wśród pót Elizejskich. Rozmowy zmartych. Recepcja. Twórczość oryginalna, Wrocław 1976.

Winniczuk L., Lukian a piękno, „Studia Filozoficzne” 1978, nr 3.

Wolsza, J., Opis dzieł malarzy w Dialogach Lukiana. Próba analizy i interpretacji, Acta Universitatis Wratislaviensis, „Antiquitas" 1994, nr 19.

\section{Netografia}

http://pl.wikipedia.org/ hasło: Uczeń czarnoksiężnika (P. Dukas).

http://j_uhma.republika.pl/uczen.html

\section{Filmografia}

Disney W. (reż.), Fantasia, 1940, Walt Disney Productions.

Hahn D., Glebas F. (reż.), Fantasia 2000, 1999, Walt Disney Feature Animation.

Turtletaub J. (reż.), The Sorcerer's Apprentice, 2010, Walt Disney Picture.

\section{STRESZCZENiE}

Film Jona Turteltauba zatytułowany Uczeń czarnoksiężnika (2010) wydaje się nie mieć, na pierwszy rzut oka, żadnych antycznych nawiązań. Aby znaleźć ukryte w nim połączenia, musimy cofnąć się do roku 1797, kiedy to Johann Wolfgang Goethe opublikował swoją słynną balladę Der Zauberlehrling. Prawie sto lat później, ta praca zainspirowała francuskiego kompozytora, Paula Dukasa, do napisania dzieła, scherzo symfonicznego pt. L'apprenti sorcier. Muzyka P. Dukasa staje się motywem przewodnim filmów W. Disneya: Fantazja (1940) i Fantazja 2000 (1999), opartych na fabule ballady J. W. Goethego. To właśnie w tym miejscu dotykamy korzeni antycznej tradycji tego filmu. Dobry przyjaciel J. W. Goethego, Christopher Martin Wieland, opublikował w 1789 r. pierwsze kompletne, niemieckie tłumaczenie Lukiana z Samosat (120-180 n.e.), w tym 
dialog Philopseudes (Egarz albo niedowiarek). Dziesiąta historia opowiedziana w Philopseudesie okazuje się bardzo podobna do ballady napisanej przez J. W. Goethe, którą następnie wykorzystali W. Disney i J. Turteltaub w swoich filmach. W moim artykule staram się pokazać transmisję tekstu Lukiana od starożytności do jego współczesnej ekranizacji. Oryginalna opowieść Lukiana, przejęta przez J. W. Goethego, staje się bardzo wpływowym dziełem kultury. Właśnie z niego czerpie źródło tak zwany „syndrom ucznia czarnoksiężnika” obecny w wielu fantastycznych opowieściach, kiedy to człowiek nie może zapanować nad swoim tworem (np. robotem), a który w końcu buntuje się przeciw swojemu stwórcy. Moim głównym celem było pokazanie, jak historia młodego ucznia czarnoksiężnika zmieniała się na przestrzeni wieków i jaką uzyskała formę w filmowych obrazach.

Słowa kluczowe: Lukian, uczeń, czarnoksiężnik, recepcja, W. Disney, P. Dukas, film, Fantazja

\section{In Search of the Sorcerer's Apprentice: Between Lucian and Walt Disney}

\section{Summary}

At first glance, Jon Turteltaub's movie entitled The Sorcerer's Apprentice (2010) seems to have no connections whatsoever with Greco-Roman antiquity. To find any hidden connections, we have to go back to 1797, when Johann Wolfgang Goethe published his famous ballad Der Zauberlehrling. Almost a century later, this work has inspired French composer Paul Dukas to write his masterpiece, the symphonic scherzo L'apprenti sorcier. Dukas' music became the leitmotif of two Walt Disney movies: Fantasia (1940) and Fantasia 2000 (1999). This is where we trace the ancient roots of the Sorcerer's Apprentice story. In 1789, a good friend of Goethe, Christopher Martin Wieland, is reported to have published the first German translation of Lucian of Samosata's (120-180 AD) complete works, including a dialogue entitled Philopseudes (The Lover of Lies). The tenth story told in Philopseudes turned out to be very similar to the one written by Goethe and then adapted into Disney's and Turteltaub's movies. In my paper I try to show the transmission of the Lucianic text from antiquity to the modern film adaptations. The original Lucian's tale, rewritten by Goethe, has proven very influential and prolific. The so-called "sorcerer's apprentice syndrome" can be found at the root of many fantastic stories in which a human being could not control his creation (i.e. a robot) which eventually would turn against its maker. The main focus in this paper is on the evolution of the young apprentice's story and its cinematographic life.

\section{Keywords}

Lucian, Sorcerer, Apprentice, reception, W. Disney, P. Dukas, film, Fantasia 